Review article

\title{
Pain assessment tools in patients with artificial ventilation
}

\author{
Alena Kohlová ${ }^{1,2,3}$ *, Katarína Žiaková ${ }^{1}$ \\ ${ }^{1}$ Comenius University in Bratislava, Jessenius Faculty of Medicine in Martin, Department of Nursing, Martin, Slovak Republic \\ 2 Jan Evangelista Purkyně University in Ústí nad Labem, Faculty of Health Studies, Department of Nursing and Midwifery, Ústí nad Labem, \\ Czech Republic \\ ${ }^{3}$ Jan Evangelista Purkyně, University in Ústí nad Labem, Masaryk Hospital in Ústí nad Labem, Clinic of Anaesthesiology, Perioperative and Intensive \\ Medicine, Ústí nad Labem, Czech Republic
}

\begin{abstract}
The objective of this literature review was to find the tools used for pain assessment in patients with artificial ventilation who cannot verbalize their pain.

The research was conducted based on systematic browsing of the available electronic licensed and freely available databases of Ebsco, Nursing Ovid, PubMed, Scopus and Web of Science. The following key words were used for the searches: pain assessment, pain management, intensive care, critical care, nursing. References acquired from the primary search were further selected to meet the following criteria: focus on pain assessment in intensive care (ICU) patients, studies presenting a unidimensional or multidimensional tool. The tool testing was carried out in patients spontaneously ventilating, or those with artificial ventilation. The tool was tested for usability and psychometric characteristics.

In this phase, 1,153 full-text documents were found using the criteria. The final list contained 14 research studies upon an analysis carried out. Six measurement tools assessing pain in patients with artificial ventilation were established. Based on the analysis and comparison of the established tools, the most suitable tool for pain assessment in patients with artificial ventilation appears to be the Behavioural Pain Scale and The Critical Care Observation Tool. Presently, there are a number of measurement tools which can be used to assess pain in patients with artificial ventilation. However, none of them are validated for the Czech nursing environment in terms of language and culture. The use of a suitable and valid tool to assess pain in patients with artificial ventilation who cannot verbalize pain is fundamental for this group of patients in order to detect and eliminate pain.
\end{abstract}

Keywords: Artificial ventilation; Intensive care; Pain; Pain assessment tool

\section{Introduction}

Pain is a significant symptom in patients hospitalized in intensive and resuscitation care units. It is frequently multifactorial, with the pain resulting not only from the disease pathology but also from therapeutic and nursing interventions (Dehghani et al., 2014). It is a stressful symptom and, if not sufficiently controlled and managed, it has a number of undesirable psychological and physiological consequences for patients. Insufficient and inappropriate pain treatment has been proved to be connected with increased morbidity and mortality rate (Akça et al., 1999; Chapman et al., 2008; Shannon and Bucknall, 2003). Pain assessment is the first and necessary step to manage it. Since pain is subjective, patient self-assessment is considered the gold standard - although this is not always possible to achieve. Self-assessment of pain is based on reliable communication between the patient and the nursing staff. The patient's ability to communicate is often reduced due to sedatives, delirium or artificial ventilation. In such cases, the nursing stuff frequently rely on their subjective pain assessment which might not be adequate for the patient. According to the International Association for the Study of Pain (IASP TWG, 2012), the inability to verbalize pain does not exclude the possibility that the patient experiences pain. If patient self-assessment cannot be used for pain assessment, an alternative measure to assess pain should be the use of validated assessment tools based on behavioural and physiological indices detecting the presence of pain (Barr et al., 2013). Research studies dealing with pain in intensive care show that in more than half of critically ill patients pain is not regularly monitored (Latorre Marco et al., 2016; Payen et al., 2007), although a systematic pain assessment using valid tools is necessary for the correct treatment of pain and can be used as an indicator of the quality of clinical practice (Skrobik et al., 2010; Wøien and Bjørk, 2013).

Foreign literature and practice provide a number of suitable tools for pain assessment in patients who cannot verbal-

\footnotetext{
* Author for correspondence: Alena Kohlová, Comenius University in Bratislava, Jessenius Faculty of Medicine in Martin, Department of Nursing, Malá Hora 5, 03601 Martin, Slovak Republic; e-mail: alena.kohlova@ujep.cz http://doi.org/10.32725/kont.2018.005

Submitted: 2018-04-21 • Accepted: 2018-11-02 • Prepublished online: 2019-01-11 
ize their pain. This issue is not being given adequate attention in the Czech Republic or in Slovakia in research or in clinical practice. No study looking into pain assessment in patients who cannot verbalize pain was found. Even the latest available Czech publication (Bartůněk et al., 2016), which deals with intensive care nursing, fails to mentions other methods of pain assessment in critically ill patients other than using verbalization. Introducing a suitable assessment tool for patients who cannot verbalize the presence of pain is necessary for Czech intensive care nursing practice. The Czech Accreditation Committee has specified the obligation to identify the procedure of pain assessment in the valid accreditation standards "... for all categories of patients (including children and persons unable to communicate verbally) and it will provide for the relevant screening tools - scales" (Marx and Vlček, 2013). The systematic and consistent use of a suitable pain assessment tool in patients unable to verbalize pain will optimize pain management and treatment in ICU patients.

\section{Materials and methods}

The objective of the literature review was to find tools used for pain assessment in patients with artificial ventilation who cannot verbalize pain, and to compare the used tools with respect to their tested psychometric properties and application in nursing practice.

The search for relevant documents was carried out in the licensed and free publicly-accessible full-text resource electronic databases of nursing and other medical fields, such as Ebsco, Nursing Ovid, Science Direct and Web of Science.

The search for relevant resources was carried out from December 2017 to February 2018. The search languages were English, Czech and Slovak. The time period identified for the searched published resources was 2000-2017. The search strategy period was selected after the start of the development and testing of tools used for pain assessment in patients with artificial ventilation. The following key words were used for searching the databases: pain assessment, pain management, intensive care, critical care, nursing, nonverbal in combination with the use of Boolean operators OR and AND; the same search criteria were used in each of the above-stated databases.

On the basis of the set selection criteria, quantitative studies were included in the analysis which: (a) dealt with pain assessment in adult ICU patients; (b) described a unidimensional or multidimensional tool for pain assessment; (c) testing was carried out in spontaneously ventilating patients or ICU patients with artificial ventilation; (d) the tool was tested for its utilization and/or psychometric properties. Research studies dealing with pain assessment outside intensive and resuscitation care units, studies dealing with newborns, infants and children and studies dealing with chronic pain assessment were excluded from the analysis.

The final review contained 14 research studies which met the required criteria after the specified selection process. Flowchart 1 shows the procedure of the search strategy.

\section{Results}

Current foreign scientific resources feature a different approach to pain assessment in patients with artificial ventilation who cannot verbalize the presence of pain. Several measurement tools to identify pain were developed in this group of

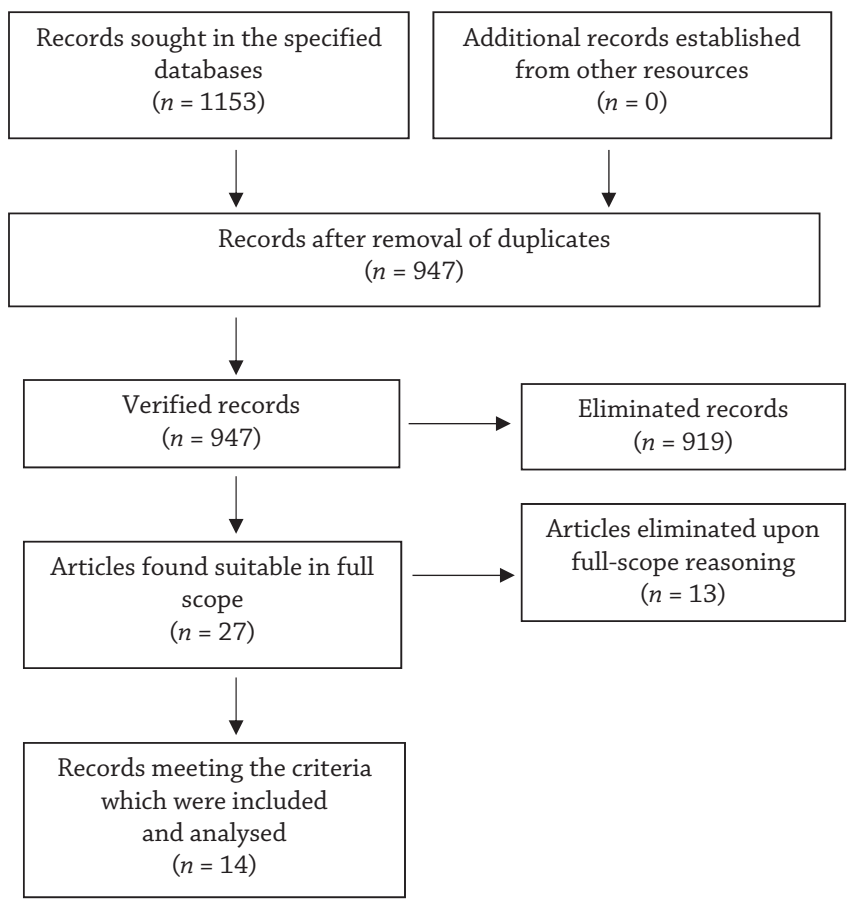

Diagram 1. Flowchart - PRISMA recommendations

patients. The following measurement tools were used in the studies dealing with the tools used for pain assessment in ICU patients with artificial ventilation: Pain Assessment and Intervention (PAIN), Nonverbal Pain Assessment Tool (NPAT), Nonverbal Pain Scale (NVPS), Scale of Behavioural Indicators of Pain (ESCID), Behavioural Pain Scale (BPS), and The Critical Care Pain Observation Tool (CPOT). A list of the quoted studies meeting the identified selection criteria is given in Table 1.

\section{Pain Assessment and Intervention (PAIN)}

The PAIN algorithm (Puntillo et al., 2002) was developed in 2001 and consists of three parts: pain assessment, patient's ability to tolerate opiates, and instructions for the selection of analgesic treatment. Part of the tool related to pain assessment is based on the identification of 6 behavioural domains (motion, posture, facial expression, sound expression, paleness and perspiration) and 3 physiological pain indicators (increase in blood pressure, heart rate and respiratory rate). 11 nurses took part in the initial testing of the tool, using the tool in a sample of 31 post-operative patients. The algorithm was assessed by the authors as useful in providing a "systematic approach" to pain assessment and analgesia management. Nonetheless, 4 of the 11 participating nurses assessed the tool as unsuitable for everyday practice as it is time-demanding and "difficult to use". The validity and reliability of the tool were not identified. The time demands of the tool limited its clinical usability and no further testing was carried out. Despite this, Puntillo et al. (2002) came to the conclusion that the tool can be a suitable training technique for new intensive care nurses.

\section{Nonverbal Pain Assessment Tool (NPAT)}

The NPAT measurement tool consists of 5 behavioural categories (emotions, motion, sound expression, facial expression and positioning/nursing). The assessment tool features two independent scoring systems which can also be used in patients who can verbalize pain. Each category contains a scale 
Table 1. Studies included in the review

\begin{tabular}{|c|c|c|c|c|}
\hline $\begin{array}{l}\text { Author/year } \\
\text { of testing }\end{array}$ & Tool & Assessment areas & Tool psychometric properties & Comments \\
\hline $\begin{array}{l}\text { Puntillo et al., } \\
2002\end{array}$ & $\begin{array}{l}\text { Pain } \\
\text { assessment } \\
\text { and } \\
\text { intervention } \\
\text { (PAIN) }\end{array}$ & $\begin{array}{l}\text { BD: motion, posture, } \\
\text { facial expression, } \\
\text { sound expression } \\
\text { FI: blood pressure, } \\
\text { heart rate, respiratory } \\
\text { rate, paleness, } \\
\text { perspiration }\end{array}$ & Not tested & $\begin{array}{l}\text { Further testing was limited } \\
\text { by time demands. The authors } \\
\text { assessed the tool as a suitable } \\
\text { training method for new ICU } \\
\text { nurses. }\end{array}$ \\
\hline $\begin{array}{l}\text { Klein et al., } \\
2010\end{array}$ & $\begin{array}{l}\text { Nonverbal } \\
\text { Pain } \\
\text { Assessment } \\
\text { Tool (NPAT) }\end{array}$ & $\begin{array}{l}\text { BD: emotions, motion, } \\
\text { sound expression, } \\
\text { facial expression, } \\
\text { positioning/nursing }\end{array}$ & $\begin{array}{l}\text { Inter-rater reliability: } 0.69 \text { ( } 95 \% \text { confidence interval) } \\
\text { Validity: } 0.66 \text { (95\% confidence interval) }\end{array}$ & $\begin{array}{l}\text { The authors assessed the tool as } \\
\text { easy to use, however, no further } \\
\text { testing of its validity or reliability } \\
\text { was carried out. }\end{array}$ \\
\hline $\begin{array}{l}\text { Odhner et al., } \\
2003\end{array}$ & $\begin{array}{l}\text { Nonverbal } \\
\text { Pain Scale } \\
\text { (NVPS) }\end{array}$ & $\begin{array}{l}\mathrm{BD} \text { : facial expression, } \\
\text { activity, defence } \\
\text { FI: blood pressure, } \\
\text { respiratory rate, } \mathrm{SpO}_{2}\end{array}$ & $\begin{array}{l}\text { Inter-rater reliability: Cronbach's } \alpha 0.78 \text {, } \\
p<0.0001\end{array}$ & \\
\hline $\begin{array}{l}\text { Kabes et al., } \\
2009\end{array}$ & & & $\begin{array}{l}\text { Inter-rater reliability: Cronbach's } \alpha=0.35 \text { before, } \\
\alpha=0.72 \text { during, } \alpha=0.71 \text { after a painful intervention }\end{array}$ & $\begin{array}{l}\text { The authors reviewed the tool and } \\
\text { replaced one FI with a respiration } \\
\text { domain. }\end{array}$ \\
\hline $\begin{array}{l}\text { Marmo and } \\
\text { Fowler, } 2010\end{array}$ & & & Inter-rater reliability: Cronbach's $\alpha=0.89$ & \\
\hline $\begin{array}{l}\text { Wibbenmeyer } \\
\text { et al., } 2011\end{array}$ & & & $\begin{array}{l}\text { Inter-rater reliability: Pearson correlation coefficient } \\
0.59 \\
\text { Internal consistency: Cronbach's } \alpha 0.80\end{array}$ & \\
\hline $\begin{array}{l}\text { Chanques et } \\
\text { al., } 2014\end{array}$ & & & $\begin{array}{l}\text { Inter-rater reliability: weighted coefficient } \kappa 0.71 \pm \\
0.04, P<0.05 \\
\text { Internal consistency: Cronbach's } \alpha=0.76\end{array}$ & \\
\hline $\begin{array}{l}\text { Latorre Marco } \\
\text { et al., } 2011\end{array}$ & $\begin{array}{l}\text { Scale of } \\
\text { Behavioural } \\
\text { Indicators of } \\
\text { Pain (ESCID) }\end{array}$ & $\begin{array}{l}\text { BD: facial expression, } \\
\text { motion activity, } \\
\text { muscle tone, comfort, } \\
\text { ventilator tolerance }\end{array}$ & Internal consistency: Cronbach's $\alpha=0.70$ up to 80 & $\begin{array}{l}\text { The scale was not tested outside } \\
\text { Spain. }\end{array}$ \\
\hline $\begin{array}{l}\text { Latorre Marco } \\
\text { et al., } 2016\end{array}$ & & & Inter-rater reliability: Cronbach's $\alpha=0.85$ & \\
\hline $\begin{array}{l}\text { Payen et al., } \\
2001\end{array}$ & $\begin{array}{l}\text { Behavioural } \\
\text { Pain Scale } \\
\text { (BPS) }\end{array}$ & $\begin{array}{l}\text { BD: facial expression, } \\
\text { motion of upper } \\
\text { limbs, ventilation } \\
\text { tolerance }\end{array}$ & $\begin{array}{l}\text { Internal consistency: Cronbach's } \alpha=0.95 \\
\text { Inter-rater reliability: in rest, } r^{2}=0.71(P<0.01) \text {, } \\
\text { during a painful stimulus, } r^{2}=0.50(P<0.01)\end{array}$ & $\begin{array}{l}\text { The BPS tool was assessed as a } \\
\text { tool which takes } 2-5 \text { minutes. } \\
\text { The tool also has a modification } \\
\text { for spontaneously ventilating } \\
\text { patients, where the "ventilation" } \\
\text { domain may be replaced with the } \\
\text { "vocalization" domain. }\end{array}$ \\
\hline $\begin{array}{l}\text { Ahlers et al., } \\
2010\end{array}$ & & & $\begin{array}{l}\text { Internal consistency: Cronbach's } \alpha=0.63 \text { in heavily } \\
\text { sedated patients; } 0.66 \text { in moderately sedated patients } \\
\text { Inter-rater reliability: } \kappa=0.80 \text { in heavily sedated } \\
\text { patients, } \kappa=0.66 \text { in moderately sedated patients }\end{array}$ & \\
\hline $\begin{array}{l}\text { Olsen et al., } \\
2015\end{array}$ & & & $\begin{array}{l}\text { Inter-rater reliability (degree of agreement among } \\
\text { raters) } \kappa=0.46-1.0 \\
\text { Discriminant validity at rest: } \varnothing=3.2 ; \\
\text { positioning: } \varnothing=4.2\end{array}$ & $\begin{array}{l}\text { The tool testing was carried } \\
\text { out as part of the algorithm } \\
\text { development for pain assessment } \\
\text { and treatment. }\end{array}$ \\
\hline $\begin{array}{l}\text { Gélinas et al., } \\
2006\end{array}$ & $\begin{array}{l}\text { Critical } \\
\text { Care Pain } \\
\text { Observation } \\
\text { Tool (CPOT) }\end{array}$ & $\begin{array}{l}\text { BD: facial expression, } \\
\text { motion activity, } \\
\text { muscle tone, } \\
\text { compliance with UPV }\end{array}$ & $\begin{array}{l}\text { Content validity index: from } 0.88 \text { to } 1.0 \text { using } \\
\text { questionnaire research. Inter-rater reliability: weighted } \\
\text { coefficient }=0.52-0.88 \\
\text { Criteria validity: } \varnothing 1.62-3.65 \text { in patients who reported } \\
\text { pain; } \varnothing 0.49-2.11 \text { in patients without pain }\end{array}$ & $\begin{array}{l}\text { The tool also has a modification } \\
\text { for spontaneously ventilating } \\
\text { patients, where the "ventilation" } \\
\text { domain may be replaced with the } \\
\text { "vocalization" domain. }\end{array}$ \\
\hline $\begin{array}{l}\text { Gélinas et al., } \\
2009\end{array}$ & & & $\begin{array}{l}\text { Feasibility: } 78.8-100 \% \\
\text { Usefulness } 54.5-72.7 \%\end{array}$ & \\
\hline $\begin{array}{l}\text { Marmo and } \\
\text { Fowler, } 2010\end{array}$ & & & $\begin{array}{l}\text { Reliability: Cronbach's } \alpha=0.89 \\
\text { Inter-rater concordance: } 56-100 \%\end{array}$ & \\
\hline $\begin{array}{l}\text { Wibbenmeyer } \\
\text { et al., } 2011\end{array}$ & & & $\begin{array}{l}\text { Internal consistency: Cronbach's } \alpha=0.71 \\
\text { Discriminant validity: } 0.27 \text { in patients at rest, } \\
0.56 \text { in patients after a painful stimulus }\end{array}$ & \\
\hline
\end{tabular}


from 0 to 2, which gives a total assessment in the range from 0 to 10 , i.e., the same range of assessment used in patients able to verbalize pain, where 0 means "no pain" and 10 designates "the worst pain" the patient has ever experienced. Klein et al. (2010) tested NPAT in 3 phases of validity testing and in 2 revisions. The first phase comprised testing in 71 patients who were able to verbalize pain. The correlation coefficient congruence was 0.31 ( $95 \%$ confidence interval). 69 patients who were not able to verbalize pain were included to specify the inter-rater reliability. The correlation coefficient congruence was 0.69 (95\% confidence interval). The NPAT was revised based on the low validity and moderately high inter-rater reliability. To specify the inter-rater reliability of the revised tool the assessment was carried out in 39 patients. The correlation coefficient congruence was 0.71 (95\% confidence interval). The revised NPAT validity was 0.21 (95\% confidence interval). The low validity of the second version of the tool led to a further revision of the tool. The third phase of the reliability validity of the assessment tool was carried out in 50 patients who had had surgery. The correlation coefficient congruence was 0.66 (95\% confidence interval). The initial NPAT testing showed a medium high validity and inter-rater reliability of the tool. NPAT is easy to use and provides the opportunity for pain assessment in patients unable to verbalize pain. Apart from the study, no other validity or reliability testing of this tool was completed.

\section{Nonverbal Pain Scale (NVPS)}

The NVPS scale is based on the FLACC measurement tool (Pedersen et al., 2017) commonly used for pain assessment in infants and pre-school children. It is based on assessment in the following areas: facial expression, motion of limbs, activity, outcry/crying and mitigation, and is not primarily specified for pain assessment in adult patients. Similarly to the PAIN algorithm, the NPAT assessment scale contains both behavioural domains (facial expression, activity, defence) and physiological indicators (changes in blood pressure, respiratory activity, $\mathrm{SpO}_{2}$ ). Each domain is scored from 0 to 2 with the total score from 0 (no pain) to 10 (maximum pain). Initial testing was conducted by Odhner et al. (2003) in 59 patients, with 100 pair assessments carried out. The inter-rater reliability was high $(\alpha=$ $0.78, P<0.001)$. Further testing of the NVPS scale was carried out by a research team from the Creighton University Medical Center (Kabes et al., 2009), which consequently revised the tool. The revised version replaced one physiological domain with a respiration domain. The assessment was carried out in ICU patients before and after a painful nursing intervention and at rest. The inter-rater reliability level was high $(\alpha=0.35$ before the intervention, $\alpha=0.72$ during the intervention and $\alpha=0.71$ after the intervention). Both the original version of the NVPS and the revised version showed considerable differences between the patient assessment before, during and after a painful nursing intervention (original: $\alpha=135.86, P<$ $0.001 ; n=121$; revised: $\alpha=145.5, P<0.01, n=121)$. The same measurement tool was used by Marmo and Fowler (2010) in patients after cardiac surgery. The assessment was carried out in 25 critically ill patients before, during and after the endotracheal tube suctioning and positioning. NVPS was assessed by them as reliable with a coefficient $\alpha=0.89$. A similar study with 38 burn patients was conducted by Wibbenmeyer et al. (2011). The assessment was done before and shortly after a painful intervention (wound re-bandaging, rehabilitation) in patients who were able to verbalize pain. NVPS showed good internal consistency $(\alpha=0.80)$, however, the inter-rater reliability was only corrective (Pearson correlation coefficient
$0.59 ; P<0.1)$. The correlation between NVPS and pain self-assessment by patients was low (Pearson correlation coefficient 0.38 ; $P<0.1$ ), which assessed NVPS as an unsuitable pain assessment tool. Similar to this study, the study conducted by Chanques et al. (2014) also assessed NVPS as an unsuitable tool for patients who can verbalize pain, as Cronbach's alpha coefficients showed a significant difference in the assessment in patients who can verbalize pain and in patients who cannot ( $\alpha=0.79$ in ventilated and $\alpha=0.46$ in spontaneously ventilating patients, $P<0.001)$. The inter-rater reliability of the tool was assessed using the weighted coefficient $\kappa(0.71 \pm 0.04 ; P<$ $0.05)$. On the other hand, NVPS showed satisfactory internal consistency ( $\alpha=0.76$ ) in this study. Yet, as an assessment tool NVPS generally shows good inter-rater reliability, validity and internal consistency in patients who are unable to verbalize pain.

\section{Scale of Behavioural Indicators of Pain (ESCID)}

A tool assessing ESCID behavioural indicators of pain was developed and validated by the Spanish research team of Latorre Marco et al. (2011). The ESCID tool consists of 5 items (facial expression, motion activity, muscle tone, comfort, ventilator tolerance). Every item is assessed on a scale from 0 to 2 . The initial testing was carried out in 42 patients with artificial ventilation. Inter-rater reliability was tested using Cronbach's alpha coefficient, which included patient self-assessment before, during and after tracheal suction and his/her positioning. The ESCID tool showed good internal consistency ( $\alpha=0.70$ up to $\alpha=0.80$ ). High reliability of ESCID was proved by another study conducted by Latorre Marco et al. (2016). It was carried out at 14 hospitals across Spain. The study looked at 286 ventilated patients who could not verbalize their pain. 4,386 ratings were carried out in total. ESCID was found to be internally reliable with $\alpha=0.85$. The ESCID tool for pain assessment in patients with artificial ventilation was found to be valid and reliable by the authors. No study dealing with the ESCID tool outside Spain was found.

\section{Behavioural Pain Scale (BPS)}

The BPS measurement tool is based on work by Puntillo (1990) which identified unique behaviour in patients who had to undergo unpleasant and painful procedures. The BPS tool was developed in French and afterwards translated into English. BPS consists of three rating domains (facial expression, motion of upper limbs, ventilator tolerance), where each domain is scored from 1 to 4 , with higher figures indicating greater discomfort. The total BPS assessment may be from 3 (no pain) to 12 (greatest pain). Payen et al. (2001) tested the tool using a quasi-experiment in 30 patients. Patients were assessed at rest and then during a painless (re-bandaging of the central venous catheter) nursing intervention and during a painful nursing procedure (endotracheal tube suctioning, positioning). Patients who underwent a painful procedure showed a higher BPS score (range of 4.6-5.2) than those with painful nursing intervention (score range of 3.3-3.7). The inter-rater reliability was high $(\alpha=0.94)$ and 24 out of 28 raters found BPS to be an easy-to-use tool with 2-5 minutes of time needed. Ahlers et al. (2010) examined the reliability and validity of BPS in 80 intensive care patients. In total, they carried out 175 ratings in patients at rest, during a painless procedure, during a painful procedure and after a painful procedure. The inter-rater reliability was excellent ( $\kappa=0.80$ in heavily sedated patients and $\kappa=0.66$ in moderately sedated patients). The internal consistency was moderate $(\alpha=0.63$ in heavily sedated patients and $\kappa=0.66$ in moderately sedated patients). The BPS 
values were higher during painful interventions both in heavily sedated patients and in moderately sedated ones (average $5.1 ; 95 \% \mathrm{Cl}$, and 3.4; $95 \% \mathrm{Cl}$ ), thus the construct validity was specified. The BPS scale was included in the research project conducted by Olsen et al. (2015) as well. Its objective was to develop an algorithm for the systematic assessment and treatment of pain in intensive care units in Norway. The algorithm included the BPS and BPS-NI measurement tools (BPS-NI can be used in patients not connected to ventilation yet who are unable to describe their pain fully). The BPS and BPS-NI values were different in patients at rest and in patients who had to undergo a painful intervention (positioning). The reliability of rater congruence in BPS was specified between average and very good ( $\kappa=0.46-1.0)$, and in BPS-NI between acceptable and good ( $\kappa=0.21-0.63)$. Discriminant validity was specified using the Wilcoxon signed-rank test in positioning and in patients at rest in bed. 30 pair ratings of the pain level using BPS and BPS-NI were carried out. The BPS-NI measurement tool showed a higher average score both in patients at rest in bed $(\varnothing=3.5)$ and in positioning $(\varnothing=4.9)$ as opposed to BPS which showed an average in patients at rest $(\varnothing=3.2)$ and in positioning $(\varnothing=4.2)$. Despite the lower results of both measurement tools compared to other studies (Ahlers et al., 2010; Payen et al., 2001), both assessment tools showed differences in the pain level in patients at rest in bed and those in positioning.

\section{The Critical Care Pain Observation Tool (CPOT)}

The CPOT tool (Gélinas et al., 2008) was created on the basis of retrospective reviews specifying common nursing and treatment procedures which cause pain in patients in intensive care units. This assessment tool is specified for use in patients with artificial ventilation as well as in patients who do not need artificial ventilation. It consists of 4 domains (facial expression, motion, muscle tension and ventilator tolerance) each of which is scored from 0 to 2 . The total score of the tool ranges from 0 (no pain) to 8 (maximum pain). The CPOT measurement tool contains descriptors based on proofs functionally definable for each area. The content validity index in the first testing ranged from $\alpha=0.88$ to $\alpha=1.0$, according to the results of the questionnaire research in which ICU nurses and physicians took part. CPOT was developed in French, much like BPS, and was tested in 105 patients after cardiac surgery first by the research team of Gélinas et al. (2006). Patient observation was carried out at rest, immediately after positioning and 20 minutes after the end of positioning. The inter-rater reliability was medium high to high (weighted coefficient $=0.52-0.88$ ) in testing between the two investigators. The criteria validity was specified by comparing the final CPOT score and pain self-assessment by the patient. The average score in patients who reported pain was 1.62-3.65. The average score in patients reporting no pain was 0.49-2.11. Gélinas et al. (2009) carried out a retrospective data analysis and assessed the sensitivity and specificity of this tool. They found that the tool showed a specificity of $78 \%$ and sensitivity of $86 \%$ during painful interventions. However, the authors assessed the reduction in sensitivity before a painful procedure at $83 \%$, and $63 \%$ after an intervention inflicting pain. The tool specificity remained high: $83 \%$ before and $97 \%$ after an intervention. Marmo and Fowler (2010) found the tool to be highly reliable $(\alpha=0.89)$ in cardiac surgery patients. They were also the first to report internal consistency of CPOT with $56-100 \%$ concordance. High internal consistency was also reported by Wibbenmeyer et al. (2011) in the CPOT tool $(\alpha=0.71)$, and good discriminant property, with an average value of the scale of 0.27 at patients in rest and 0.56 after a painful intervention.

\section{Discussion}

The published evidence shows that there are several tools used for pain assessment in patients who cannot verbalize pain due to their connection to artificial ventilation. 6 tools were identified based on the available literature resources. They are designed for pain assessment in this specific group of patients. According to the available literature resources, some tools were tested more than others. The pain assessment tools in ventilated ICU patients can be divided into two groups: unidimensional assessment tools and multidimensional assessment tools. Multidimensional tools are based on the assessment of behavioural domains together with physiological indicators, unlike unidimensional tools, which assess only behavioural domains and exclude the use of physiological indicators. The NAPT, ESCID, BPS and CPOT assessment tools can be classified as unidimensional tools assessing patients with artificial ventilation who cannot verbalize pain. The PAIN algorithm and NVPS scale can be classified as multidimensional tools. Both tools assess facial expression and activity in behavioural domains. PAIN also assesses sound expression, unlike NVPS, which assesses patients' defence in this domain. Both assessment tools assess blood pressure and respiratory rate in the physiological indicators. The PAIN algorithm also shows increased heart rate, paleness and perspiration as symptoms of pain. NVPS shows the decrease in $\mathrm{SpO} 2$ and vice-versa. Unidimensional tools assessing patients with artificial ventilation are based on behavioural domains and exclude physiological indicators. NPAT and ESCID assess patients using five behavioural descriptors, CPOT four and BPS only three descriptors. The descriptors "facial expression" and "motion activity" in the behavioural dimension were included in all 4 unidimensional assessment tools. The BPS assessment tool in "motion activity" is the only tool focusing only on upper extremities, as opposed to NAPT, ESCID and CPOT, which assess motion of the whole patient's body. Another shared descriptor represented in the ESCID, BPS and CPOT tools is the assessment of so-called tolerance or ventilator tolerance. Both the NPAT and CPOT assessment tools assess muscle tone. Of the group of unidimensional tools, together with the PAIN algorithm from multidimensional tools, NPAT is the only one to assess sound expression. This area, however, cannot be used in patients with artificial ventilation as the air does not pass the vocal cords, which cannot then work. One exception is the CPOT tool, which also contains the "vocalization" descriptor in its construction, but only as a replacement for the "ventilation" descriptor for spontaneously ventilating patients. The possibility to choose one or the other descriptor allows it to be used in a wider group of ICU patients. CPOT is not the only tool which can be used in patients who can verbalize pain as well as in patients with artificial ventilation. Modification of BPS and NPAT can also be used for both of the above-stated groups of patients. However, they have independent scoring systems which already need to be selected prior to the beginning of testing, unlike CPOT, where only the relevant corresponding descriptor, which is part of the tool, is selected, instead of the whole tool. The PAIN algorithm and NPAT assessment tool were published only in one study each, and their clinical usability was not further tested. The clinical usability of the PAIN tool was limited not only by the use of physiological indicators specified as insufficiently sensitive for the detection of pain (Pasero and McCaffery, 2005; Payen et al., 2001), but also by its length and time demands. Four of the eleven nurses participating in testing PAIN assessed the algorithm as "too long and difficult to use", and as more 
suitable as a training technique for new nurses than for use in clinical practice. Despite being designed for critically ill ICU patients, the NPAT tool was not validated in this population and two out of three tests were carried out in surgery patients who were able to verbalize pain. This fact could reduce the clinical confidence of its use in critically ill ventilated ICU patients. The Spanish ESCID assessment tool was also tested with some limitations as well. Despite showing good internal consistency, it contains the majority of shared elements of consideration in behavioural domains, such as BPS and CPOT, and was tested only in Spain. The multidimensional NVPS assessment tool ranks in the group of tools which were tested more, together with BPS and CPOT, although pain is assessed upon behavioural and physiological indicators. NVPS is the only assessment tool which contains the assessment "smile" and "lying in normal position" in the behavioural domain, which cannot be considered an "inappropriate" condition. The CPOT and BPS assessment scales are suggested by studies as an ideal tool for pain assessment in patients with artificial ventilation. The internal consistency and inter-reliability of both scales were established in more than one prospective study. Nevertheless, when comparing the study results, CPOT shows better internal consistency than BPS (Cronbach's $\alpha=0.71-0.89$ vs. Cronbach's $\alpha=0.63-0.66$ in the specific ranking). The results of construction, criterial and discriminant analyses of validity in several different groups of patients were favourable both for CPOT and BPS, despite the greater number of statistical analyses used in CPOT. Moreover, sensitivity (86\%) and specificity (78\%) were retrospectively investigated only in CPOT as the only tool contained in our list. In terms of construction, all the mentioned assessment tools require spontaneous, neuromuscular transmitted physical activity which can be observed by another person. Patients who cannot provide such a response (tetraplegia, neuromuscular disorders or relaxed patients), cannot be assessed under these assessment tools.

\section{Conclusions}

The selection of a suitable pain assessment tool in patients who cannot verbalize pain is a challenging issue. Searching for and studying published works dealing with the specific issue is beneficial and useful for an update in the current development in this field. Systematic pain assessment should be carried out regularly and patients should be the primary source for pain assessment whenever possible. 6 validated tools used for pain assessment in patients with artificial ventilation were established. On the basis of an analysis, the Behavioural Pain Scale and The Critical Care Observation Tool proved to have good to excellent validity and reliability based on the testing, and seem to be the most suitable pain assessment tools in patients who cannot verbalize pain. Yet, they are not appropriate for the whole diagnostic spectrum of ICU patients, since behavioural rating tools require the presence of a spontaneous, neuromuscular mediated response. Patients with tetraplegia or neuromuscular disorders cannot be assessed using these tools. Further studies need to be conducted to deal with suitable tools to detect pain across the whole diagnostic spectrum of critically ill ventilated patients who cannot verbalize pain.

Since there is no suitable tool used for the detection of pain in patients who cannot verbalize pain, it is necessary, based on the research, to identify one from the offered tools which can be used in the Czech nursing environment, and integrate it into nursing practice as a standard procedure for the detection and treatment of pain in patients who cannot verbalize pain.

\section{Conflict of interests}

The authors have no conflict of interests to disclose.

\section{Nástroje pro hodnocení bolesti u pacientů na umělé plicní ventilaci}

\section{Souhrn}

Cílem literárního přehledu bylo vyhledat nástroje používané pro hodnocení bolesti u pacientů na umělé plicní ventilaci, kteří nemohou verbalizovat svoji bolest.

Výzkum se uskutečnil na základě systematického vyhledávání v dostupných elektronických licencovaných a volných dostupných databázích Ebsco, Nursing Ovid, PubMed, Scopus a Web of Science. Pro hledání ve výše uvedených databázích byla použita tato klíčová slova: pain assessment, pain management, intensive care, critical care, nursing. Reference získané prvotním vyhledáváním byly podrobeny užšímu výběru, tak aby splnily následující kritéria: zaměření na hodnocení bolesti u pacientů v intenzivní péči, studie prezentující jednorozměrný nebo multidimenzionální nástroj, testování nástrojů probíhalo u pacientů spontánně ventilujících nebo na umělé plicní ventilaci, nástroj byl testován na využitelnost a psychometrické vlastnosti.

Pomocí těchto kritérií bylo v této fázi nalezeno 1153 plnotextů. Po analýze bylo do konečného přehledu zahrnuto 14 výzkumných studií. Bylo dohledáno šest měřicích nástrojů zaměřených na hodnocení bolesti u pacientů na umělé plicní ventilaci. Na základě analýzy a komparace dohledaných nástrojů se jako nejvhodnější nástroj pro hodnocení bolesti u pacientů na umělé plicní ventilaci jeví nástroje Behavioral Pain Scale a The Critical Care Observation Tool. V současné době existuje řada měřicích nástrojů, které mohou být použity k hodnocení bolesti u pacientů na umělé plicní ventilaci, ovšem žádný z nich není jazykově a kulturně validován pro české ošetřovatelské prostředí. Používání vhodného a platného nástroje pro posouzení bolesti u pacientů na umělé plicní ventilaci, kteří nemohou verbalizovat př́tomnost bolesti, je u této skupiny pacientů základem pro detekci a eliminaci bolesti.

Klíčová slova: bolest; intenzivní péče; nástroj hodnocení bolesti; umělá plicní ventilace 


\section{References}

1. Ahlers SJ, van der Veen AM, van Dijk M, Tibboel D, Knibble CA (2010). The use of Behavioral Pain Scale to assess pain in conscious sedated patients. Anesth Analg 110(1): 127-133. DOI: 10.1213/ANE.0b013e3181c3119e.

2. Akça O, Melischek M, Scheck T, Hellwagner K, Arkiliç CF, Kurz A, et al. (1999). Postoperative pain and subcutaneous oxygen pension. Lancet 354(9172): 41-42. DOI: 10.1016/ S0140-6736(99)00874-0.

3. Barr J, Fraser GL, Puntillo K, Ely EW, Gélinas C, Dasta JF, et al. (2013).Clinical practice guidelines for the management of pain, agitation, and delirium in adult patients in the intensive care unit: Executive summary. Am J Health Syst Pharm 70(1): 53-58.

4. Bartůněk $P$, Jurásková D, Heczková J, Nalos D (2016). Vybrané kapitoly z intenzivní péče. Praha: Grada Publishing.

5. Chanques G, Pohlman A, Kress JP, Molinari N, Jong de A, Jaber S, et al. (2014). Psychometric comparison of three behavioural scales for the assessment of pain in critically ill patients unable to self-report. Critical Care 18 R160. DOI: $10.1186 /$ cc14000.

6. Chapman CR, Tuckett RP, Song CW (2008). Pain and stress in systems perspective: reciprocal neural, endocrine, and imine interactions. J Pain 9(2): 122-145. DOI: 10.1016/j. jpain.2007.09.006.

7. Dehghani H, Tavangar H, Ghandehari A (2014). Validity and reliability of behavioral pain scale in patients with low level of consciousness due to head trauma hospitalized in intensive care unit. Arch Trauma Res 3(1): e18608. DOI: 10.5812/atr.18608.

8. Gélinas C, Fillion L, Puntillo K, Viens C, Fortier M (2006). Validation of the Critical-Care Pain Observation Tool for nonverbal adult patients. Am J Crit Care 15(4): 420-427.

9. Gélinas C, Fillion L, Puntillo KA (2008). Item selection and content validity of the Critical-Care Pain Observation Tool for non-verbal adults. J Adv Nurs 65(1): 203-216. DOI: $10.1111 / j .1365-2648.2008 .04847 . x$.

10. Gélinas C, Harel F, Fillion L, Puntillo K, Johnston C (2009). Sensitivity and specificity of the Critical-Care Observation Tool for the detection of pain in intubated adults after cardiac surgery. J Pain Symptom Manage 37(1): 59-67. DOI: 10.1016/j. jpainsymman.2007.12.022.

11. IASP TWG (2012). International association for the study of pain; pain taxonomy. [online] [cit. 2018-03-05]. Available from: http://www.iasp-pain.org/Taxonomy

12. Kabes AM, Graves JK, Norris J (2009). Futher validation of the Nonverbal Pain Scale in intensive care patients. Crit Care Nurse 29(1): 59-66. DOI: 10.4037/ccn2009992.

13. Klein DG, Dumpe M, Katz E, Bena J (2010). Pain assessment in the intensive care unit: development and psychometric testing of the Nonverbal Pain Assessment Tool. Heart Lung 39(6): 521-528. DOI: 10.1016/j.hrtlng.2010.05.053.

14. Latorre Marco I, Solíz Muñoz M, Falero Ruiz T, Larrasquitu Sánchez A, Romay Peréz AB, Millán Santos I (2011). Grupo del proyecto de Investigación ESCID. Validación de la Escala de condustas indicadoras de dolor para valorar el dolor en pacientes críticos, no comunicativos y sometidos a ventilación mecánica: resultados del proyecto ESCID. Enferm Intensiva 22: 3-12. DOI: 10.1016/j.enfi.2010.09.005.

15. Latorre-Marco I, Acevedo-Nuevo M, Solíz-Muñoz M, Hernándes-Sánchez L, López-López C, Sánchez-Sánchez MM, et al. (2016). Psychometric validation of the behavioral indicators of pain scale for the assessment of pain in mechanically ventilated and unable to self-report critical care patients. Med Intensiva 40(8): 463-473. DOI: 10.1016/j.medin.2016.06.004

16. Marmo L, Fowler S (2010). Pain assessment tool in critically il post-open heart surgery patient population. Pain Manag Nurs 11(3): 134-140. DOI: 10.1016/j.pmn.2009.05.007.

17. Marx D, Vlček F (2013). Akreditační standardy pro nemocnice: obsahující hodnoticí požadavky specifikované v přiloze č. 1 vyhlášky MZ ČR č. 102/2012 Sb., o hodnocení kvality a bezpečí lůžkové zdravotní péče. Praha: SAK společně s TIGIS.

18. Odhner M, Wegman D, Freeland N, Steinmetz A, Ingersoll G (2003). Assessing pain control nonverbal critically ill adults. Dimens Crit Care Nurse 22(6): 260-267.

19. Olsen BF, Rustøen T, Sandvik L, Miaskowski C, Jacobsen M, Valeberg BT (2015). Development of a pain management algorithm for intensive care units. Heart Lung (44): 521-527. DOI: 10.1016/j.hrtlng.2015.09.001.

20. Pasero C, McCaffery M (2005). No self-report means no painintensity rating. Am J Nurs 105(10): 50-53.

21. Payen JF, Bru O, Bosson JL, Lagrasta A, Novel E, Deschaux I, et al. (2001). Assessing pain in critically ill sedated patients by using a behavioral pain scale. Crit Care Med 29(12): 2258-2263.

22. Payen JF, Chanques G, Mantz J, Hercule C, Auriant I, Leguillou JL, et al. (2007). Current Practices in Sedation and Analgesia for Mechanically Ventilated Critically Ill Patients. Anesthesiology 106(4): 687-695. DOI: 10.1097/01. anes.0000264747.09017.da.

23. Pedersen LK, Rahbek O, Nikolajsen L, Møller-Madsen B (2017). Assessment of pain in children with cerebral palsy focused on translation and clinical feasibility of the revised FLACC score. Scand J Pain 9(1): 49-54. DOI: 10.1016/j.sjpain.2015.06.005.

24. Puntillo K, Stannard D, Miaskowski C, Kehrle K, Gleeson S (2002). Use of a pain assessment and intervention notation (P.A.I.N) tool in critical care nursing practice: nurses' evaluations. Heart Lung 31: 303-314.

25. Puntillo K (1990). Pain experiences of intensive care unit patients. Heart Lung 19(5 Pt 1): 526-533.

26. Shannon K, Bucknall T (2003). Pain assessment in critical care: what have we learnt from research. Intensive Crit Care Nurs 19(3): 154-162.

27. Skrobik Y, Ahern S, Leblanc M, Marquis F, Awissi DK, Kavanagh PB (2010). Protocolized Intensive Care Unit Management of Analgesia, Sedation, and Delirium Improves Analgesia and Subsyndromal Delirium Rates. Anesthesia 111(2) 451-463. DOI: 10.1213/ANE.0b013e3181d7e1b8.

28. Wibbenmeyer L, Sevier A, Liao J, Williams I, Latenser B, Lewis R 2nd, et al. (2011). Evaluation of the usefulness of two established assessment tools a burn population. J Burn Care res 32(1): 52-60. DOI: 10.1097/BCR.0b013e3182033359.

29. Wøien H, Bjørk IT (2013). Intensive care pain treatment and sedation. Intensive and critical care nursing. Intensive Crit Care Nurs 29(3): 128-136. DOI: 10.1016/j.iccn.2012.11.003. 